\begin{tabular}{|l|l|l||}
\hline \multicolumn{2}{|c|}{ PublisherInfo } \\
\hline \hline PublisherName & $:$ & BioMed Central \\
\hline \hline PublisherLocation & $:$ & London \\
\hline \hline PublisherImprintName & $:$ & BioMed Central \\
\hline \hline
\end{tabular}

\title{
The heart of the matter
}

\begin{tabular}{|l|l|l||}
\hline \multicolumn{2}{|c|}{ ArticleInfo } \\
\hline \hline ArticleID & $:$ & 4662 \\
\hline \hline ArticleDOI & $:$ & $10.1186 /$ gb-spotlight-20021218-01 \\
\hline \hline ArticleCitationID & $:$ & spotlight-20021218-01 \\
\hline \hline ArticleSequenceNumber & $:$ & 328 \\
\hline \hline ArticleCategory & $:$ & Research news \\
\hline \hline ArticleFirstPage & $:$ & 1 \\
\hline \hline ArticleLastPage & $:$ & 2 \\
\hline \hline & & RegistrationDate : 2002-12-18 \\
ArticleHistory & $:$ & OnlineDate $\quad$ 2002-12-18 \\
\hline \hline ArticleCopyright & $:$ & BioMed Central Ltd2002 \\
\hline \hline ArticleGrants & $:$ & \\
\hline \hline ArticleContext & $:$ & 130593311 \\
\hline \hline
\end{tabular}




\section{Jonathan B Weitzman}

Email: jonathanweitzman@hotmail.com

In humans, heart injury leads to the formation of scar tissue and cardiomyocyte hypertrophy, but the heart does not regenerate. In the December 13 Science Kenneth Poss and colleagues, at Harvard Medical School in Boston, show that zebrafish hearts are able to regenerate after injury without scarring (Science 2002, 298:2188-2190). Surgical removal of $20 \%$ of the ventricular myocardium from adult fish induced initial fibrin clot formation. The clot was then replaced by cardiac myofibers, and by two months after injury the hearts appeared grossly normal. Bromodeoxyuridine (BrdU) incorporation experiments showed extensive proliferation of cardiomyocytes near the surgery site. Cardiac injury in fish with a temperature-sensitive mutation in the mps1 gene, encoding a mitotic checkpoint kinase, led to the formation of large, connective-tissue scars in the absence of proliferation. These results provide an interesting model with which to investigate the molecular mechanisms underlying cardiac regeneration, and hint at the potential to manipulate cardiomyocyte proliferation in mammalian hearts.

\section{References}

1. Science, [http://www.sciencemag.org]

2. Harvard University, [http://www.harvard.edu]

3. Mps1 defines a proximal blastemal proliferative compartment essential for zebrafish fin regeneration 